\title{
Synergy effect in GUI usability and accessibility education improvement
}

\author{
Magdalena Borys, Marek Milosz \\ and Malgorzata Plechawska- \\ Wojcik \\ Lublin University of Technology \\ Lublin, Poland \\ m.borys@pollub.pl, \\ marekm@cs.pollub.pl, \\ gosiap@cs.pollub.pl
}

\author{
Sergio Luján Mora \\ Universidad de Alicante \\ Alicante, Spain \\ sergio.lujan@ua.es
}

\author{
Sybille Caffiau \\ Université Joseph Fourier, Grenoble \\ I \\ Grenoble, France \\ sybille.caffiau@imag.fr
}

\begin{abstract}
The paper presents the synergy effect from knowledge and experience exchange in the field of Graphical User Interface (GUI) usability and accessibility among Leonardo da Vinci Partnerships project partners. The main aims of the project are curricula and teaching materials development in the usability and accessibility of computer applications area. Partner universities join their potential in order to achieve the planned results.
\end{abstract}

Keywords - usability and accessibility education, synergy effect, educational project

\section{INTRODUCTION}

Information technology is now one of the fastest growing areas of science. Institutions offering IT education programs are trying to adapt the curriculum to current technologies and trends as fast as possible. But the advancement of these curricula in software engineering, software development methods and techniques, programming languages, etc., is not adequate to the development of usability and accessibility of those software interfaces.

A large number of existing IT systems were developed without taking into consideration the actual needs and capabilities of the user. Many organizations and companies more and more often become aware of the gap between developed system features and needs and capabilities of the user [1][2]. What is more, there is growing body of national laws and policies address accessibility of ICT, including the Internet and the Web [3]. Therefore, there is noticeable and growing demand for the specialists of graphical user interface usability and accessibility in software industry who be able to bridge the mentioned gap and thus improve the quality of software.

The paper describes the project of collaboration between universities and industry representative in the frame of Leonardo da Vinci Lifelong Learning Programme. The paper presents the synergy effect from knowledge and experience exchange in the field of GUI usability and accessibility among the project partners used to respond to the needs of the labour market through developing or adjusting existing curricula of usability and accessibility at partners universities at European level. In particular

\section{USABILITY AND ACCESSIBILITY EDUCATION}

Usability and accessibility are closely related [4]. Usability refers to the extent in which a IT system is easy to learn, remember and use by users; and accessibility refers to the quality of a system being in situation to be used by all kind of users including those who have specific types of cognitive, physical, or perceptual disabilities, including people with agerelated impairments [5]. Usability is also considered to be one of the most important quality factor for applications, directly affecting on user performance (effectiveness, efficiency) and satisfaction [6].

Usability and accessibility are topics of many recent research conducted by academic, research and professional staff. The results of their work are widely presented at research conferences. But these topics are not incorporated into student classes. Then, the strong effort is necessary to integrate these resources and gained knowledge into teaching materials.

GUI usability and accessibility are not among the disciplines that can be learned from the book, in a purely theoretical manner. To become professional in the field, the combination of theoretical expertise and practical experience is required. According to that, it is important to share knowledge in the field of usability and accessibility as well as to develop and improve teaching methods through cross-fertilization of experience among the European educational institutions. 


\section{THE PROJECT DESCRIPTION}

The project "GUI usability and accessibility: exchanging knowledge and experiences (AUKEE)" was established in the frame of Leonardo da Vinci (LdV) Lifelong Learning Programme in Partnerships action. years.

The project has started in September 2012 and it will last 2

\section{A. The project objectives}

A Leonardo da Vinci is a framework for small-scale cooperation activities between organizations working in the field of vocational education which will be cooperating on themes of mutual interest to the participating organizations. Partnerships action enables to conduct peer learning activities for the use of common tools as described in the Helsinki Communiqué, such as transparency, EQF, ECVET, quality assurance, excellence of skills, competences for key sectors [7].

Leonardo da Vinci Partnerships follow the objectives of the Leonardo da Vinci Programme, which reflect the general political goals of vocational education and training (VET) policy at European level [8]. Particularly, the project takes into account present priority topics in common VET policy such as responding to the needs of the labour market, especially of SMEs, anticipation of skills needed in labour market and improve the qualification of teachers.

The following list defines the major objectives of the project which include:

- $\quad$ adjusting the curriculum in the field of usability and accessibility to the real needs of labour market,

- developing a set of usability and accessibility elearning teaching resources,

- raising professional qualifications of academic teachers,

- establishing an international research group.

To reach those objective the following milestones were established during project kick-off meeting:

- The curriculum for GUI usability and the curriculum for GUI accessibility - December 2012.

- Draft e-learning materials for GUI usability - April 2013.

- Evaluation of e-learning materials for GUI usability June 2013.

- E-learning materials for GUI usability - October 2013.

- Draft e-learning materials for GUI accessibility January 2014.

- Evaluation of e-learning materials for GUI accessibility - March 2014.

- E-learning materials for GUI accessibility - May 2014.
- Publishing e-learning materials as massive open online course - June 2014.

- $\quad$ Project evaluation - August 2014.

\section{B. Partners backgrounds}

The partnership of the LdV project AUKEE includes:

- Lublin University of Technology (Poland),

- University of Alicante (Spain),

- Joseph Fourier University (France),

- ICT company KARO Studio s.c. (Poland).

The Lublin University of Technology (LUT) is a state university and functions under the supervision of the Polish Ministry of Higher Education and Science.

At present, there are six faculties and several and interfaculty units at LUT. LUT employees about 1,100 academic teachers. There are about 11.000 students, where 6.500 are full time students, 4.200 part time students, 220 post diploma participants and $115 \mathrm{PhD}$ students.

LUT education proceeds within 12 main study courses. One of them is Computer Science carried out by Institute of Computer Science at Faculty of Electrical Engineering and Computer Science.

Institute of Computer Science, directly involved in the project realization, is leading department providing courses for IT specializations such as Internet Applications, Software Engineering, Multimedia Systems and Applications, Mobile Systems, Exploitation of IT Systems and Telecommunication Systems. Institute of Computer Science actively collaborates with local industry to adapt curricula to labor market needs.

LUT is a major education center in the Lublin region, which is recognized as disadvantaged one. It enables the equalization of educational availability between pupils from highly and low urbanized areas. It is flexible with admission of migrants, also from the eastern Europe and Asia with respect for their religious and cultural background. Staff can conduct classes in foreign languages (English and Russian).

Institute of Computer Science has carried out several software usability studies commissioned by industry and research activities in the fields of accessibility for visual impaired during the last years [9][10].

In Computer Science courses there are no subjects devoted exclusively to teaching usability and accessibility of user interface. But other subjects such as Software Engineering, Internet Application Programming or Team Project include some contents about software usability and accessibility on $1^{\text {st }}$ and $2^{\text {nd }}$ level of Higher Education. The lack of the systematic course, which will be designed for teaching usability and accessibility, is noticeable [11].

The University of Alicante (UA) was established in 1979 on the basis of the Center for University Studies (CEU), which was founded in 1968. 
UA offers courses in more than fifty degrees. It includes over seventy departments and research groups in areas of Social Science and Law, Experimental science, Technology, Liberal Arts, Education and Health Sciences, and five research institutes.

UA has more than 2.300 academic teachers and more than 1.200 staff members. During the academic year 2010-2011, more than 28.000 students enrolled in the more than 40 firstlevel studies and in the more than 30 master studies.

The Department of Software and Computing Systems (Departamento de Lenguajes y Sistemas Informáticos) is one of the biggest departments at UA, employing more than 60 fulltime teachers, more than 30 support teachers and 6 staff members. The Department of Software and Computing Systems belongs to the Polytechnic School and it is in charge of courses about software engineering, software development and multimedia systems, including content management systems and e-learning management systems.

The Department of Software and Computing Systems has carried out several research activities in the fields of software development, usability and accessibility of web sites and web applications, and e-learning during the last fifteen years.

At UA, usability and accessibility is mainly taught in four subjects: Internet Programming, Hypermedia Programming 1, Quality in the Design of Web Applications, and Quality of Computer Systems. All these subjects are currently offered by the Department of Software and Computing Systems.

Other subjects also include some small contents about usability and accessibility, but these four subjects devote to these topics a significant part of their syllabuses. Besides, usability and accessibility have also been taught in some courses not belonging to any degree.

Different lines of research on usability and accessibility are currently conducted at UA. These research lines were born from the web engineering group with more than 10 years of experience in research about web development.

On the one hand, the usability research has been focused on the usability of software development methods. In particular, the impact of Model-Driven Web Engineering approaches on the maintainability of web applications has been experimentally evaluated [12] with some remarkable results. And in the same line, the impact of a Model-Driven Web Engineering approaches on the productivity and the satisfaction of software development teams has also been evaluated [13].

On the other hand, the accessibility research has been mainly focused on the proposal of a method for the evaluation of web accessibility. More specifically, a combined accessibility evaluation method based both on qualitative and quantitative evaluation methods has been proposed [14]. Moreover, the adoption of agile software development methods has been proposal as a help to improve the accessibility of web projects. In this sense, the integration of accessibility into agile methods has been proposed [15].

UA has a strong commitment with helping disabled people. The Student Support Center (Centro de Apoyo al Estudiante), a unit devoted to provide a wide range of support to students with physical or sensorial disability, is an example of this commitment. Besides, this unit also advices teachers to adapt their teaching.

UA maintains two websites for the dissemination of knowledge about web accessibility. On the one hand, a blog (Fig. 1) was created in 2006. Since then, more than 1,000 posts have been published and more than 300 people visit this blog every day. On the other hand, a website to spread the knowledge about web accessibility was created in 2008. This website contains more than 300 pages and more than 200 people visit it every day.

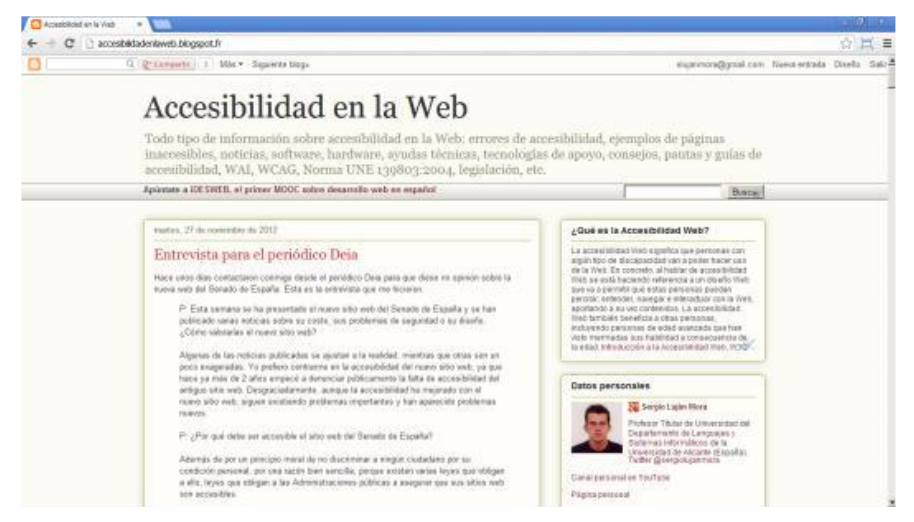

Figure 1. The blog about web accessibility at UA

The Joseph Fourier University (UJF) is one of the four universities of Grenoble in France. It proposes curricula focusing on the scientific and medical domains. Nearly 15.000 students study from their first university year to $\mathrm{PhD}$ level.

The main part of courses is performed by enseignantchercheurs (teaching and research staff position in French educational system). Each of them is member of one of the 50 research laboratories of UJF.

Human Computer Interface HCI (HCI) courses are mainly addressed to students of Master degree (and of engineering school). Student have different profiles, they may choose following course:

- French or English spoken (there are 4 French-spoken Masters and one English-spoken Master in which HCI course is included);

- Bachelor or Master specialized in another knowledge domain (like management, physics, biology and so on);

- continue their formation after Master on PhD studies;

- combine computer science knowledge with another domain.

Each of the master curricula and 2 specializations of engineering school provide HCI courses on several topics such as Web UI, models for HCI, mobile and multimodal UI, ergonomics for UI. Depending of the master specialization, each student may choose one or several topics. Usability and 
accessibility concepts are learned and applied during the HCI courses according to the main topic of the course.

At UJF there is a wide variance of knowledge level about usability and accessibility of UI (including GUI) at the end of the student formations.

The HCI courses are taught by researchers of the Grenoble Informatics Laboratory (LIG). The laboratory is composed of 23 research teams (nearly 500 researchers) and 5 of them (nearly 85 researchers) have topics of interest linked to the interactive and cognitive systems (for example, the HCI design, usage or computer vision). For this research field, usability and accessibility are elements that need to be taken into consideration [17]. In order to increase and to improve the application of usability and accessibility in the research works, an usability lab aims at providing an environment to performed user experiments by using new evaluation tools (such as heterogeneous traces) [18].

Karo-Studio s.c. (Karo-Studio), is a SME company established in 2009. It is involved into development of IT projects concerning web, desktop and mobile applications. The company gained experience in the area of usability and accessibility during development of projects focused on GUI ergonomics. Usability and accessibility of GUI is essential for the customer satisfaction. That is why Karo-Studio makes every effort to provide high quality of GUI projects. The company has experience in conducting web and applications dedicated to tactile devices projects. The company is rapidly developing. Its permanent objective is continual improvement of overall performance and achievement of the stable position in the mobile and web projects development. It is open for collaboration with European IT enterprises, universities and associations in the field of IT projects development, especially in the area of usability and accessibility.

Each partner brings an unique contribution to the project. Varied experience of the project partners in the field of usability and accessibility of user interface, the diversity of works carried out on behalf of the industry in the field of accessibility and usability, as well as the varying range of applied teaching methods allows to achieve synergies in this partnership.

LUT is a project coordinator and is responsible for supporting project partners, providing communication and evaluation of project activities and as well the project as a whole. The remaining tasks are evenly distributed between the partners.

\section{PROJECT BENEFITS}

The project benefits derive directly form objectives of the project.

The first result of project is the proposed curricula. To adjust the curricula of both GUI usability and accessibility it was necessary to recognize the real labour market needs. That is why, the curricula were developed in the close collaboration with SME ICT company included in the partnership. It allows to identify the most important and urgent needs of ICT industry like: introduction of usability designing and usability testing into software developing process or adjustment of web and mobile user interface to visually impaired and people with agerelated impairments. Additionally, in the curricula development process the previous experience (especially LIG) of cooperation between industry and universities also have impact on the curricula improvement.

The proposed curricula will help to standardize the usability and accessibility education at European level and with accordance to EQF among partner universities. The curricula will be published online, therefore any educational institution interested in it could use the curricula for its own purpose. The curricula are also presented as the base for the e-learning teaching resources, which are the other result of the project.

The set of usability and accessibility e-learning teaching resources is planned as resources that could be used as:

- an additional learning resource for traditional classes,

- a standalone e-learning course,

- $\quad$ and, after some modification, as massive open online course (MOOC, online course aimed at large-scale participation and open access).

E-learning teaching resources will be prepared jointly by all project partners. The preparation of teaching materials, both in English and native languages, will tighten the relationships between courses taught in English and those in native languages, as well as it allows expand the audience of the training materials.

Preparation of both curricula and e-learning teaching resources raises professional qualifications of academic teachers by sharing knowledge, experiences and best practices in the area of GUI usability and accessibility between partners.

In a long term the project aims to establish the international educational group as well the scientific international research group working on the similar concepts.

From students point of view, they will also benefit from the project in many ways.

Firstly, the scope of the curricula is much more comprehensive due to experience and expertise of each partner. What is more the curricula are better adjusted to actual labour market needs, so students they will have possibility to obtain more adequate skill and knowledge. Thus their attractiveness at the local and European labour market will increase after the graduation.

Secondly, students will be taught GUI usability and accessibility by more qualified academic staff thanks to experience and knowledge exchange. They will got the access to e-learning resources to expand and consolidate gained knowledge as well enhance their competencies. The form of prepared resource gives students lots of flexibility to plan their learning process and perform it.

They will be more aware on usability and accessibility issues even if their work will not be connected with user interface development or testing. 
Thirdly, students will have possibility to assess prepared elearning resources during theirs development stage to ensure the proper quality of the resources. They have the significant influence on e-learning resources content and forms.

Indirect effects include improving the capability of local SMEs in solving software interface usability and accessibility problems. What is more, the project propose to build an international community of teachers to integrate usability and accessibility in IT students education by developing lecture materials, providing seminars and workshops and conducting collaborative research.

At European level the main advantages of project are:

- increasing awareness about the advantages of the knowledge exchange,

- improvement of abilities to cooperate at research and teaching levels in international group,

- improvement of language skills in accordance to a tendency of teaching in English,

- promotion of European research results in usability and accessibility area in various languages and countries.

\section{PROPOSED CURRICULA}

During the project the curricula for GUI usability and accessibility were proposed. The curricula were elaborated jointly by partners during $1^{\text {st }}$ working meeting in two independently working teams - one team was working on usability curriculum and another team on accessibility curriculum. All partners have great contribution into creation of those curricula thanks to various experience in the project domain.

The both curricula include the core topics of, respectively, usability and accessibility in following usage areas:

- desktop application interfaces,

- Web application interfaces,

- mobile application interfaces,

- $3 \mathrm{D}$ interfaces and natural user interface (NUI).

The curricula will be used to prepare the e-learning resources for massive open online courses for GUI usability and accessibility. Each course will be one semester long and has $50 \%$ of lectures and private studies and 50\% labs and assessment workload. The assessment will include both knowledge and skills evaluation. Each proposed curriculum is estimated for 4 ECTS.

The proposed accessibility curriculum contains 8 sections (tab. 1), which include introduction to accessibility, description of types of disabilities and existing assistive technologies [19] and accessibility principles [20][21]. Then, the sections of accessibility in different area of usage are proposed and finally accessibility evaluation methods $[22,23,24,25,26]$.

TABLE I. THE ACCESSIBILITY COURSE CONTENT

\begin{tabular}{|c|c|c|c|}
\hline Lectures & [h] & Practical works & [h] \\
\hline $\begin{array}{l}\text { Introduction to accessibility: } \\
\text { definition, benefits, regulations } \\
\text { and laws, terminology. }\end{array}$ & 4 & $\begin{array}{l}\text { Classification } \\
\text { disabilities. }\end{array}$ & 2 \\
\hline $\begin{array}{l}\text { Disabilities and assistive } \\
\text { technologies: types of } \\
\text { disabilities, accessibility } \\
\text { barriers, assistive technologies - } \\
\text { hardware and software. }\end{array}$ & 4 & $\begin{array}{l}\text { Familiarize with } \\
\text { assistive technologies. }\end{array}$ & 4 \\
\hline $\begin{array}{lr}\text { Accessibility } & \text { principles: } \\
\text { accessibility guidelines and } \\
\text { standards, perceivable } \\
\text { information and user interface, } \\
\text { operable user interface and } \\
\text { navigation, understandable } \\
\text { information and user interface, } \\
\text { robust content and reliable } \\
\text { interpretation. }\end{array}$ & 6 & $\begin{array}{l}\text { Good and bad } \\
\text { accessibility practices } \\
\text { examples. Proposal of } \\
\text { accessibility problems } \\
\text { in online forum. }\end{array}$ & 4 \\
\hline $\begin{array}{l}\text { Accessibility of desktop } \\
\text { applications: accessibility APIs } \\
-\quad \text { MSAA, JAAPI; IBM } \\
\text { Software checklist. }\end{array}$ & 8 & $\begin{array}{ll}\text { Development } & \text { of an } \\
\text { accessible } & \text { desktop } \\
\text { application. } & \end{array}$ & 10 \\
\hline $\begin{array}{l}\text { Accessibility of web } \\
\text { applications: W3C guidelines - } \\
\text { WCAG 2.0, UAAG 2.0, ATAG } \\
\text { 2.0, WAI-ARIA. }\end{array}$ & 12 & $\begin{array}{l}\text { Development of an } \\
\text { accessible web site. }\end{array}$ & 10 \\
\hline $\begin{array}{l}\text { Accessibility of mobile } \\
\text { applications: relationship and } \\
\text { differences between MWBP and } \\
\text { WCAG, native applications. }\end{array}$ & 6 & $\begin{array}{l}\text { Development of an } \\
\text { accessible mobile site: } \\
\text { adaptation of the } \\
\text { desktop web site to } \\
\text { mobile environment. }\end{array}$ & 8 \\
\hline $\begin{array}{l}\text { Accessibility of 3D interfaces: } \\
\text { natural user interfaces - } \\
\text { hardware and software. }\end{array}$ & 4 & $\begin{array}{l}\text { Familiarize with } 3 \mathrm{D} \\
\text { interfaces. }\end{array}$ & 2 \\
\hline $\begin{array}{l}\text { Evaluation of accessibility: } \\
\text { evaluation methods - standards } \\
\text { review, heuristic evaluation, } \\
\text { design walkthroughs, screening } \\
\text { techniques, and accessibility } \\
\text { testing. }\end{array}$ & 6 & $\begin{array}{l}\text { Evaluation of } \\
\text { accessibility of a web } \\
\text { site. }\end{array}$ & 4 \\
\hline Total: & 50 & Total: & $\mathbf{5 0}$ \\
\hline
\end{tabular}

The proposed GUI usability curriculum is closely linked to development process. Besides the introduction to usability, there are three processes presented:

- User Centered Analysis (UCA) [27],

- User Centered Design (UCD) [28],

- Usability Testing (UT) [6].

For all of them appropriate techniques, data and tools are proposed.

TABLE II. THE USABILITY COURSE CONTENT

\begin{tabular}{|l|l|l|l|}
\hline Lectures & [h] & \multicolumn{1}{|c|}{ Practical works } & [h] \\
\hline $\begin{array}{l}\text { Introduction to usability: HCI } \\
\text { - general principles, usability. }\end{array}$ & 2 & $\begin{array}{l}\text { Usability disasters. } \\
\text { Participation in a } \\
\text { discussion forum }\end{array}$ & 2 \\
\hline $\begin{array}{l}\text { Introduction to UCA: an } \\
\text { introduction, importance of }\end{array}$ & 4 & $\begin{array}{l}\text { Video analysis. Online } \\
\text { brainstorming on the } \\
\text { specification of the } \\
\text { project }\end{array}$ & 4 \\
$\begin{array}{l}\text { log analyisis, video analysis, } \\
\text { audio analysis, eye-tracking } \\
\text { data, activity, }\end{array}$ & & \\
\hline
\end{tabular}




\begin{tabular}{|c|c|c|c|}
\hline Lectures & [h] & Practical works & [h] \\
\hline \multicolumn{4}{|l|}{$\begin{array}{l}\text { brainstorming, focus groups - } \\
\text { questionnaires, user diaries, live } \\
\text { annotation data. }\end{array}$} \\
\hline $\begin{array}{l}\text { UCA }- \text { design } \\
\text { profiles, personas, scenarious, } \\
\text { task analysic, information } \\
\text { architecture and } \\
\text { concepts. }\end{array}$ & 8 & $\begin{array}{l}\text { Definition of design } \\
\text { strategy. Card sorting } \\
\text { to define the } \\
\text { information } \\
\text { architecture of the } \\
\text { chosen applications. }\end{array}$ & 4 \\
\hline 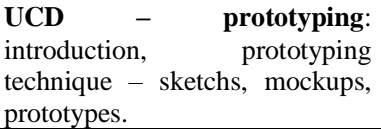 & 2 & $\begin{array}{l}\text { Build a prototype with } \\
\text { Balsamiq. }\end{array}$ & 4 \\
\hline UCD - core interface patterns. & 6 & Prototype refinement. & 2 \\
\hline $\begin{array}{l}\text { UCD - specific interactions: } \\
\text { desktop, Web, mobile and 3D } \\
\text { interfaces }\end{array}$ & 6 & Prototype refinement. & 4 \\
\hline $\begin{array}{l}\text { UCD - advanced interaction } \\
\text { patterns: post-wimp interaction. }\end{array}$ & 8 & $\begin{array}{l}\text { Discussion of existing } \\
\text { post-wimp interfaces. }\end{array}$ & 2 \\
\hline $\begin{array}{lrr}\text { Usability } & \text { testing } & - \\
\text { introduction: } & \text { general } & \text { UT } \\
\text { techniques, } & \text { experiments } \\
\text { conduction. } & & \\
\end{array}$ & 2 & & \\
\hline $\begin{array}{l}\text { Expert evaluation: } \\
\text { evaluation, } \\
\text { walkthrough. }\end{array}$ & 4 & $\begin{array}{l}\text { Build an heuristic } \\
\text { evaluation checklist. } \\
\text { Conduct an heuristic } \\
\text { evaluation. Conduct a } \\
\text { cognitive walkthrough } \\
\text { and record it in video. }\end{array}$ & 8 \\
\hline $\begin{array}{l}\text { User evaluation: remote } \\
\text { usability testing, in situ usability } \\
\text { testing, eye- tracking }\end{array}$ & 4 & $\begin{array}{l}\text { Build a remote } \\
\text { usability test. Conduct } \\
\text { a remote usability test. } \\
\text { Conduct an on-line } \\
\text { usability test. }\end{array}$ & 10 \\
\hline $\begin{array}{l}\text { Usability } \begin{array}{c}\text { testing } \\
\text { usability } \\
\text { reports } \\
\text { templates, }\end{array} \\
\text { reporting measures in usability } \\
\text { studies. }\end{array}$ & 4 & $\begin{array}{l}\text { Prepare a report for } \\
\text { the heuristic } \\
\text { evaluation. Prepare a } \\
\text { report for the remote } \\
\text { usability test. Prepare } \\
\text { a report for the in-situ } \\
\text { usability test. } \\
\text { Compare the results. }\end{array}$ & 10 \\
\hline Total: & 50 & Total: & 50 \\
\hline
\end{tabular}

\section{THE ARCHITECTURE OF E-LEARNING SYSTEM}

One of the important objective of the project is to develop e-learning resources for the implementation of curricula in GUI usability and accessibility areas. As it was mentioned, to disseminate the idea of GUI usability and accessibility the MOOC, available to everyone on the Internet, will also be prepared as well. It will be a part of open education space. MOOC resources will prepared through the adjustment of e-learning resources for students of partner universities.

To assist the process of preparing educational materials the architecture of the system were developed (Fig 2).

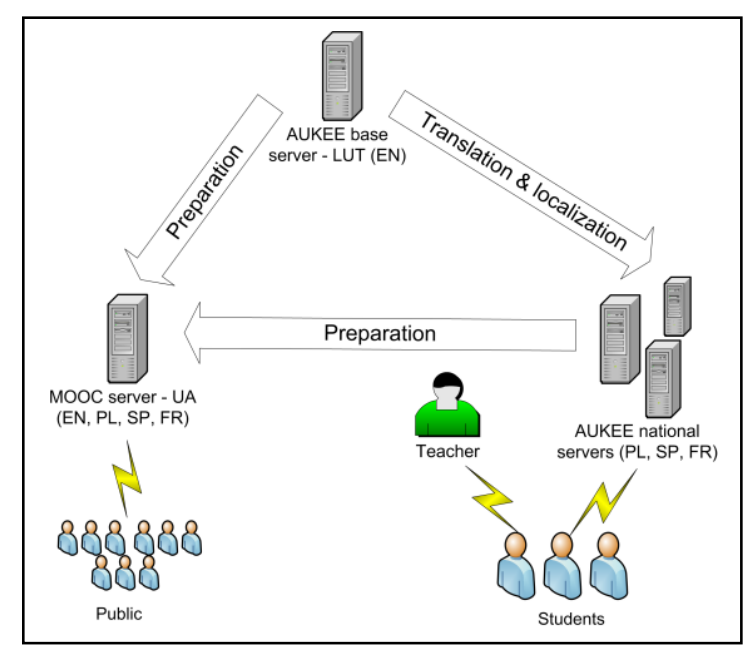

Figure 1.

The architecture of AUKEE project e-learning system

During the project AUKEE realization the e-learning resources in English will be developed firstly. They will be published and collected on a server maintained by the project coordinator - LUT (AUKEE base server in Fig. 2). The elearning resource in English will consist the base for developing e-learning courses in partners national languages (i.e. Polish, Spanish and French). Those courses in national languages will require also minor modifications like localization and adaptation to national conditions. Based on elearning resources, the content for MOOC will be developed in English and in all partners national languages. These resources will be placed on the dedicated MOOC platform at the University of Alicante (UA) (MOOC server on Fig. 2).

Partner universities have extensive experience of working in such distributed electronic environment from the previous projects [29, 30, 31, 32].

\section{CONCLUSION AND FURTHER WORK}

Since the curricula have been developed, the partners are currently working on the development of common guidelines for e-learning materials, such as video, lesson, and so on. All partners are preparing to creating e-learning courses collecting materials such as case studies, examples and so on.

Despite the project is still in realization stage, the great benefits like synergy effect from knowledge and experience sharing can be observed. The synergy effect is related not only to usability and accessibility domain, but also the teaching techniques and methods, developing learning resources and usage of modern communication tools in educational process.

The LdV project is good example of how team working can be an excellent tool for the improvement of HE education.

\section{REFERENCES}

[1] The United Nations, Convention on the Rights of Persons with Disabilities, http://www.un.org/disabilities/default.asp?navid=12\&pid=150

[2] European Union, Web accessibility policy, http://europa.eu/geninfo/accessibility_policy_en.htm

[3] World Wide Web Consortium, Policies Relating to Web Accessibility, http://www.w3.org/WAI/Policy/Overview.html

[4] Usability Body of Knowledge, http://www.usabilitybok.org

[5] Web Accessibility and Usability Working Together, http://www.w3.org/WAI/

[6] J. Nielsen, Usability Engineering, Morgan Kauffmann, San Francisco, 1993

[7] Lifelong Learning Programme, Leonardo da Vinci, http://ec.europa.eu/education/lifelong-learning-programme/ldv_en.htm 
[8] Lifelong Learning Programme, Leonardo da Vinci Partnership, http://ec.europa.eu/education/leonardo-da-vinci/partnerships_en.htm

[9] Laskowski M., Szymczyk T.; Using leisure-oriented applications for detecting potential color vision disorders; Methods of Optimisation and Data Analysis. Selected Issues; pp. 95-110; University of Szczecin 2010 (ISBN: 978-83-7518-242-2)

[10] Laskowski M., Szymczyk T., Economic and legal aspects of adjusting online advertisements for the visually impaired, Actual Problem of Economics 6 (108) 2010, pp. 301-308, National Academy of Management 2010 (ISSN: 1993-6788)

[11] M. Plechawska-Wojcik, M. Borys, Methods and technologies for quality improving of student team software projects. Proceedings of EDUCON2012, IEEE, Marrakesh, Morocco 2012.

[12] Y. Martínez, C. Cachero, M. Matera, S. Abrahão, S. Luján-Mora, Impact of MDE Approaches on the Maintainability of Web Applications: An Experimental Evaluation. ER 2011:233-246.

[13] Y. Martínez, C. Cachero, S. Meliá. Evaluating the Impact of a ModelDriven Web Engineering Approach on the Productivity and the Satisfaction of Software Development Teams. ICWE 2012:223-237.

[14] S. Luján-Mora, F. Masri. Evaluation of Web Accessibility: A Combined Method. In Pedro Isaias, Miguel Baptista Nunes (Eds.), Information Systems Research and Exploring Social Artifacts: Approaches and Methodologies, Hersey, PA: Information Science Reference, p. 314-331, 2012.

[15] S. Luján-Mora, F. Masri. Integration of Web Accessibility into Agile Methods. Proceedings of the 14th International Conference on Enterprise Information Systems (ICEIS 2012), Volume 3, p. 123-127, Wroclaw (Poland), June 28 - July 12012.

[16] World Wide Web Consortium, How to Meet WCAG 2.0, http://www.w3.org/WAI/WCAG20/quickref/

[17] S. Caffiau, P. Girard, D.L. Scapin, L. Guittet, and L. Sanou, Assessment of Object use for Task Modeling. TAMODIA 2008, (2008).

[18] M. Gallissot, J. Caelen, F. Jambon, and B. Meillon, Une plate-forme usage pour l'intégration de l'informatique ambiante dans l'habitat: Domus. Technique et Science Informatique 32, (2013).

[19] World Wide Web Consortium, Authoring Tools Accessibility Guidelines 2.0: http://www.w3.org/TR/ATAG/
[20] World Wide Web Consortium, Web Content Accessibility Guidelines 2.0: http://www.w3.org/TR/WCAG/

[21] World Wide Web Consortium, User Agent Accessibility Guidelines 2.0: http://www.w3.org/TR/UAAG/

[22] Java Accessibility API: http://docs.oracle.com/javase/7/docs/technotes/guides/access/jaapi.html

[23] IBM Software Checklist: http://www03.ibm.com/able/guidelines/software/accesssoftware.html

[24] Microsoft Active Accessibility: http://msdn.microsoft.com/enus/library/ms697707.aspx

[25] WAI-ARIA: http://www.w3.org/TR/wai-aria/

[26] W3C Mobile Web Best Practices: http://www.w3.org/TR/mobile-bp/

[27] A. Sutcliffe, User-Centred Requirements Engineering, Springer, 2002

[28] K. Vredenburg, S. Isensee, C. Righi, User-Centered Design: An Integrated Approach, Prentice Hall, 2001

[29] A. Merceron, J-M. Adam , S. Luján-Mora, M. Milosz, A. Toppinen, Faculty Development and Quality Assurance in the EU ERAMIS Project ,International Journal of Engineering Pedagogy (iJEP), Vol 2, No 3 (2012), eISSN: 2192-4880

[30] J-M. Adam, S. Lujan-Mora, A. Merceron, M. Miłosz, A. Toppinen, European-Russian-Central Asian Network of Master's degree "Informatics as a Second Competence". Proceedings of EDUCON2012 - IEEE Global Engineering Education Conference, 17-20 April 2012, Marrakesh, Morocco, pp. 722-72.

[31] S. Luján-Mora, J-M. Adam, A. Merceron, M. Milosz, A. Toppinen; Creating an International Network of Master Degrees in Computer Science as a Second Competence. Proceedings of the 4th International Conference of Education, Research and Innovation (ICERI 2011), 14-16 November 2011, Madrid, Spain, pp. 2811-2815,

[32] E. Miłosz, M. Miłosz, J-M. Adam, S. Lujan-Mora, N. Trunk Sirca, Internationalization of Higher Education - a Case Study of Leonardo da Vinci Project. Proceedings of MakeLearn 2012 Management, Knowledge and Learning International Conference, 20-22 June 2012, Celje, Slovenia, pp. 851-858. 